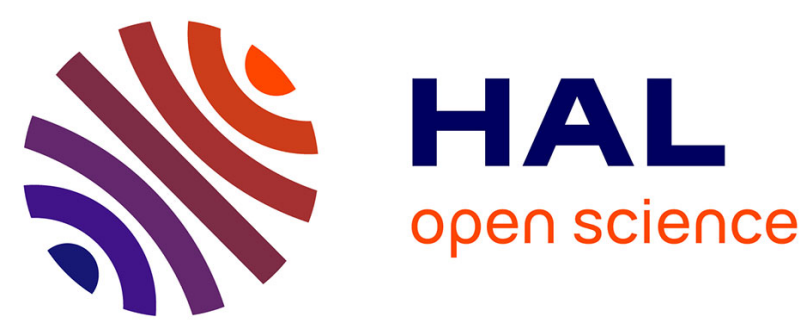

\title{
Model of the delayed translation of cyclin B maternal mRNA after sea urchin fertilization
}

Vincent Picard, Odile Mulner-Lorillon, Jérémie Bourdon, Julia Morales, Patrick Cormier, Anne Siegel, Robert Bellé

\section{- To cite this version:}

Vincent Picard, Odile Mulner-Lorillon, Jérémie Bourdon, Julia Morales, Patrick Cormier, et al.. Model of the delayed translation of cyclin B maternal mRNA after sea urchin fertilization. Molecular Reproduction and Development, 2016, 10.1002/mrd.22746 . hal-01390047

\section{HAL Id: hal-01390047 https://hal.sorbonne-universite.fr/hal-01390047}

Submitted on 31 Oct 2016

HAL is a multi-disciplinary open access archive for the deposit and dissemination of scientific research documents, whether they are published or not. The documents may come from teaching and research institutions in France or abroad, or from public or private research centers.
L'archive ouverte pluridisciplinaire HAL, est destinée au dépôt et à la diffusion de documents scientifiques de niveau recherche, publiés ou non, émanant des établissements d'enseignement et de recherche français ou étrangers, des laboratoires publics ou privés. 
Title: Model of the delayed translation of cyclin B maternal mRNA after sea urchin fertilization

Authors: Vincent Picard ${ }^{1,4,5}$, Odile Mulner-Lorillon ${ }^{2,3}$, Jérémie Bourdon ${ }^{1}$, Julia Morales $^{2,3}$, Patrick Cormier ${ }^{2,3}$, Anne Siegel $^{4,5}$ and Robert Bellé 2,3

(1) CNRS UMR 6241, Laboratoire LINA, Université de Nantes, France.

(2) Sorbonne Universités, UPMC Univ Paris 06, UMR 8227, Integrative Biology of Marine Models, Translation Cell Cycle and Development, Station Biologique de Roscoff, CS 90074, 29688 Roscoff cedex, France

(3) CNRS, UMR 8227, Integrative Biology of Marine Models, Translation Cell Cycle and Development, Station Biologique de Roscoff, CS 90074, 29688 Roscoff cedex, France

(4) CNRS, IRISA-UMR 6074, Campus de Beaulieu, 35042 Rennes, France

(5) INRIA, Centre Rennes - Bretagne Atlantique, Symbiose, Campus de Beaulieu, 35042 Rennes, France

Corresponding author:

Professeur Robert Bellé

Station Biologique, CNRS-UPMC

place Georges Teissier, CS 90074

29688 Roscoff Cedex, France.

Tel: +33 (0) 2982923 46;

fax: +33 (0) 298292306 .

e-mail: belle@sb-roscoff.fr 
Short title: a model for cyclin B biosynthesis.

Abbreviations: CDK1, cyclin-dependent kinase 1; eIF, eukaryotic initiation factor.

\section{Supporting grants}

This work was supported by the Ligue contre le cancer (Western France regional branch, Finistère, Côtes d'Armor, Deux Sèvres, Morbihan and Vendée committees), the Brittany Regional Council and the Finistère Departmental Council. This work was also partially support by the French Agency for Research (ANR10_BLANC-0218 BioTempo project) and by PEPS QuantOursin CNRS grant. Authors declare no conflict of interest. 


\section{Abstract}

Sea urchin eggs exhibit a cap-dependent increase in protein synthesis within minutes after fertilization. This rise in protein synthesis occurs at a constant rate for a great number of proteins translated from the different available mRNAs. Surprisingly, we found that cyclin $\mathrm{B}$, a major cell-cycle regulator, follows a synthesis pattern that is distinct from the global protein population, so we developed a mathematical model to analyze this dissimilarity in biosynthesis kinetic patterns. The model includes two pathways for cyclin B mRNA entry into the translational machinery: one from immediately available mRNA (mRNAcyclinB) and one from mRNA activated solely after fertilization (XXmRNAcyclinB). Two coefficients, $\alpha$ and $\beta$, were added to fit the measured scales of global protein and cyclin B synthesis, respectively. The model was reduced to identify the synthesis parameters and to allow its simulation. The calculated parameters for activation of the specific cyclin B synthesis pathway after fertilization included a kinetic constant $\left(k_{a}\right)$ of $0.024 \mathrm{sec}^{-1}$, for the activation of XXmRNAcyclinB, and a critical time interval $\left(t_{2}\right)$ of 42 minutes. The proportion of XXmRNAcyclinB form was also calculated to be largely dominant over the mRNAcyclinB form. Regulation of cyclin B biosynthesis is an example of a select protein whose translation is controlled by pathways that are distinct from housekeeping proteins, even though both involve the same cap-dependent initiation pathway. Therefore, this model should help gain insight to the signaling utilized for the biosynthesis of cyclin B and other select proteins.

Key words: translational control, deterministic model, cyclin B synthesis simulation. 


\section{Introduction}

Translation is a key process in the control of gene expression. The steps of translation (initiation, elongation, and termination) involve multiple factors that are subjected to regulation (extensively reviewed by Mathews et al. 2007; Hershey et al. 2012). The great majority of mRNAs are translated by the cap-dependent pathway, which involves the binding of the initiation factor $4 \mathrm{E}$ (elF4E) to the 5 ' end of the mRNAs that contains $\mathrm{m}^{7} \mathrm{GpppN}$, where $\mathrm{N}$ is any nucleotide (Jackson et al. 1995). The protein elF4E is a major regulator of translation initiation (Sonenberg and Gingras 1998). The availability of elF4E in cells depends on the presence of elF4Ebinding proteins (4E-BPs) that compete with the large scaffolding protein eukaryotic initiation factor 4G (elF4G) for a common binding site on elF4E (Mader et al. 1995). The binding of 4E-BPs to elF4E prevents cap-dependent translation (Haghighat et al. 1995) and is a source for translation regulation (Cormier et al. 2003; Cormier et al. 2016).

The sea urchin embryo has been used to understand two crucial cellular processes: protein translation regulation and control of the cell cycle (Hunt 2002; Cormier et al. 2003; Gilbert 2013; Cormier et al. 2016). The sea urchin genome did not undergo whole-genome duplication, so translational control factors are encoded by non-redundant genes (Morales et al. 2006; Sodergren et al. 2006). An increase in protein synthesis occurs at fertilization, which is required for completion of the first cell cycle and thus for the initiation of development (Epel 1990). This initial increase in protein synthesis is independent of new transcription, instead involving maternal mRNAs already present in the unfertilized egg (Epel 1967; Brandhorst 1976). Fertilization also provokes many changes in egg metabolism that could contribute to 
translation regulation (Epel 1990; Parrington et al. 2007; Gilbert 2013). Fertilization triggers $4 \mathrm{E}-\mathrm{BP}$ release from elF4E, and consequently cap-dependent translation through an mTOR-sensitive pathway (Cormier et al. 2001; Salaun et al. 2003; Chasse et al. 2016; Cormier et al. 2016). A mechanism of 4E-BP regulation was first demonstrated in the sea urchin, wherein the 4E-BP pool rapidly disappears following fertilization (Salaun et al. 2003; Salaun et al. 2004; Salaun et al. 2005; Oulhen et al. 2007; Oulhen et al. 2010).

Fertilized sea urchin eggs are released from a block in the $\mathrm{G} 1$ phase of the cell cycle by a mechanism involving new protein synthesis. Thus, regulation of protein synthesis is intimately linked with regulation of the cell cycle. Early steps of translation take place from maternally available mRNAs. Although transcription of some mRNAs was demonstrated to occur soon after fertilization in the sea urchin (Wilt 1970; Brandhorst 1980), these transcripts are not required for the first cleavages (Gross and Cousineau 1963). In contrast, protein synthesis is mandatory for embryonic cell divisions (Wagenaar 1983; Dube 1988) - in particular, the synthesis of cyclins (Evans et al. 1983). For example, cyclin B associates with preexisting cyclin-dependent kinase 1 (CDK1) to form the CDK1:cyclin B complex, which drives the cell cycle (Hunt 2002; Murray 2004; Malumbres 2014). Cyclin B is abruptly degraded after induction of $M$-phase, allowing for $M$ phase exit and progression of the cell cycle (Hunt 2002; Murray 2004; Malumbres 2014). The de novo synthesis of cyclin $B$ is then necessary for a new cell cycle to occur. The role of both CDK1 and cyclin B was discovered in and named for this cyclic behavior in the sea urchin (Evans et al. 1983).

Analysis of how translation regulates gene expression concluded that transcript levels by themselves are not sufficient to predict protein abundance in 
many scenarios (Hershey et al. 2012; Liu et al. 2016). Several models were presented that attempt to understand the mRNA translation process (Komar et al. 2012; Zhao and Krishnan 2015). Eukaryotic mechanisms for translation initiation were traditionally separated into cap-dependent and cap-independent (or IRESmediated) pathways, but this is an oversimplification (Komar et al. 2012). Capdependent translation may be the major route to initiate mRNAs for housekeeping proteins, whereas mRNAs coding for regulatory proteins may possess additional or alternative routes for entry into cap-dependent translational machinery (Hershey et al. 2012; Komar et al. 2012).

We previously detailed an integrative model for cap-dependent translation (Belle et al. 2010) and a parsimonious numerical model involving 4E-BP and elF4E regulation that successfully fit with experimental results and predicted the regulation of 4E-BP abundance at fertilization (Laurent et al. 2014). The latest model also accommodated the increase in global protein synthesis accompanying fertilization (Laurent et al. 2014). Here, we empirically compared global protein and cyclin B synthesis. This approach necessitated the normalization of many different experimental data, which revealed a distinct dynamic profile for cyclin B synthesis compared to global protein synthesis. We then sought to revise the initial model to incorporate the observed difference between global protein and cyclin B biosynthesis. Hypothesizing that mRNA for cyclin B exists in two forms, with one not immediately available for translation, provided a better fit to the experimental data. The model now predicts that activation of the not-immediately-available form of mRNA accounts for almost $95 \%$ of cyclin B synthesis and takes place 42 minutes after fertilization. The parameters deduced from the model can now be used to design further experiments for understanding why two pathways evolved. 


\section{Results}

\section{Biological measurements reveal a specific pattern for cyclin B accumulation}

Global protein synthesis following fertilization was measured by $\left[{ }^{35} \mathrm{~S}\right]-\mathrm{L}-$ methionine incorporation after pre-loading the sea urchin eggs with the radioactive amino acid. Global protein synthesis increased as a function of time after fertilization (Fig. 1, blue spots). The profiles of the newly synthesized proteins, as determined following electrophoretic resolution and autoradiography (Fig. 2), were comparable at different times after fertilization, as previously documented (Salaun et al. 2003; Chasse et al. 2016). Analysis of protein synthesis by pulse experiments, beginning at different time points after fertilization, revealed that the rate of synthesis increases from 0 to 30 minutes, and then remains constant up to 180 minutes (Fig. 3). Therefore, global protein synthesis uniformly affects almost all proteins, with a constant rate of synthesis from the available quantity of respective mRNAs.

The specific synthesis of cyclin B was determined by purifying $\left[{ }^{35} \mathrm{~S}\right]$-cyclin $\mathrm{B}$ from extracts. Labeled cyclin B was detected as a 45-47 $\mathrm{kDa}$ doublet on autoradiograms, which were then quantified by densitometric analysis. Values were harmonized among the independent experiments, which involved different parents, by standardizing all data as fractions of the maximum value. Mean values of cyclin $B$ biosynthesis following fertilizations from 6 independent experiments were obtained, and revealed that cyclin B abundance increased progressively, reaching a maximum around 90-105 minutes after fertilization, and was abruptly degraded around 120 minutes after fertilization - which is after M-phase of the cell cycle, just prior to cytokinesis (Fig. 1, red points). No direct comparison between a representative, 
unique protein and cyclin B was possible, so a comparison between global protein and specific cyclin B synthesis was obtained by adapting the scales so that values were comparable at the 60-min time point (Fig. 1, arrowed), when the kinetics of both are linear. In other words, the kinetics of global protein synthesis was used to represent a typical protein whose radioactive intensity would be the same as the radioactivity present in cyclin $B$ at the 60 minutes time point after fertilization.

Control experiments were performed by immunoblotting for cyclin B to determine if the purification protocol was selecting a particular pool of cyclin B. The kinetics of cyclin B accumulation determined by immunoblotting was highly comparable with that of purified $\left[{ }^{35} \mathrm{~S}\right]-$ cyclin $\mathrm{B}$, except that maternal cyclin $\mathrm{B}$ was detectable by immunoblot unfertilized eggs (i.e. time zero), as already reported (Chasse et al. 2016); this abundance increased about five fold following fertilization. The purification protocol was therefore preferred for analysis of de novo cyclin B synthesis after fertilization.

A summary of these differences in protein synthesis, within the context of morphological changes that follow fertilization, is shown in Figure 1. The blue points represent the kinetics of accumulation of newly synthesized (radiolabelled) global proteins whereas red points represent cyclin B. The amounts of each were scaled to the same units. The accumulation of newly synthesized cyclin B after fertilization is strikingly delayed compared to total protein, suggesting distinct regulation of translational activation for cyclin B mRNA.

\section{Model elaboration and justification}

A previous minimal model (Laurent et al. 2014) simulated the decrease in protein 4E-BP abundance at fertilization, modifying the equilibrium between 
elF4E:4E-BP and elF4E:elF4G complexes and triggering the increase in global protein synthesis that is characteristic of the initial phase of embryo development. A more detailed model was developed to investigate the dissimilarity between cyclin B and global protein synthesis dynamics observed at fertilization.

We first hypothesized that cyclin B mRNA was present in two forms, one that was immediately available for translation (mRNAcyclinB) and another that was not immediately available (XXmRNAcyclinB). The XXmRNAcyclinB messenger would be present in unfertilized oocytes and transformed upon fertilization into a form available for translation, referred to as XXmRNAcyclinBactive. For homogeneity, the mRNAs available for 4E-BP (mRNA4E-BP) and for global protein (mRNAProtein) synthesis by the cap-dependent pathway were also added to the model for homogeneity. The possibility that a unique mRNA for cyclin B may be gene-specific translated (Wek 1994; Fraser 2009; Hinnebusch et al. 2016; Young and Wek 2016) had been considered, but was not retained (see Discussion).

The reaction graph corresponding to the model is shown in Figure 4. The specific reactions considered, and their parameters, are as follows:

$$
\begin{aligned}
& \mathrm{R} 1 ; 2: \text { elF4E }+4 \mathrm{E}-\mathrm{BP}<=>\text { elF4E:4E-BP } \quad\left(\mathrm{k}_{\text {off }} / \mathrm{k}_{\text {on } 1}\right) \\
& \text { R3;4 : elF4E + elF4G <=> elF4E:elF4G } \quad\left(\mathrm{k}_{\text {off }} / \mathrm{k}_{\text {on } 2)}\right) \\
& \text { R5 : elF4E:elF4G + mRNA4E-BP }=>\text { elF4E:elF4G + mRNA4E-BP + 4E-BP ( }\left(k_{\text {cat }}\right) \\
& \text { R6 : elF4E:elF4G + mRNAProtein } \left.=>\text { elF4E-elF4G + mRNAProtein + Protein ( } k_{\text {cat }}\right) \\
& \mathrm{R} 7: 4 \mathrm{E}-\mathrm{BP}=>0 \quad\left(\mathrm{k}_{\text {lysis4E-BP }}\right) \\
& R 8: \text { XXmRNAcyclinB }=>\text { XXmRNAcyclinBactive }\left(k_{a}\right) \\
& \text { R9 : elF4E:elF4G + mRNAcyclinB => elF4E:elF4G + mRNAcyclinB + cyclinB_1 } \\
& \left(\mathrm{k}_{\text {cat }}\right)
\end{aligned}
$$


R10 : elF4E:elF4G + XXmRNAcyclinBactive $=>$ elF4E:elF4G

+XXmRNAcyclinBactive + cyclinB_2 $\left(\mathrm{k}_{\text {cat }}\right)$

The first 7 reactions were derived from the previous minimal model (Laurent et al. 2014), with the addition of parameters mRNA4E-BP (R5) and mRNAProtein (R6). Reactions 8,9 , and 10 correspond to the minimal reactions required for the analysis of cyclin B biosynthesis. mRNAcyclinB corresponds to the mRNA available for cyclin B synthesis (R9) via pathway 1 (cyclinB_1), while XXmRNAcyclinB needs to be activated to XXmRNAcyclinBactive following fertilization (R8), before it is available for cyclin B synthesis through pathway 2 (cyclinB_2) (R10). All mRNAs were assumed to be translated by a cap-dependent pathway, and therefore to be dependent on the amount of elF4E:elF4G complex and on the corresponding amounts of mRNA; an identical reaction constant $\left(\mathrm{k}_{\mathrm{cat}}\right)$ was assumed (see Discussion). Similarly to the previously published model, elF4E is always considered to be associated with mRNA since the affinity and stability of the elF4E:cap-structure of mRNA is very high (Sonenberg and Gingras 1998). The total amount of elF4E and elF4G also remain constant after fertilization (Oulhen et al. 2007).

Several parameters were considered for the simulation experiments and parameter determinations. Similar to the previous simplified model (Laurent et al. 2014), a delay for full activation ( $\delta$ ) and a time interval ( $t$ ) from time zero (fertilization) were considered for the parameters $\mathrm{k}_{\text {cat }}, \mathrm{k}_{\text {off }}, \mathrm{k}_{\text {lysisis4E-BP, and }} \mathrm{k}_{\mathrm{a}}$. Two coefficients, $\alpha$ and $\beta$, were also integrated into the model in order to fit the scales for respectively global protein and cyclin B synthesis - which was necessitated by the different experimental protocols for each determination.

\section{Differential equations}


The differential equations from the reactions and considerations above were solved as:

(1) $d[\mathrm{eIF} 4 \mathrm{E}] / d t=k_{\mathrm{off} 1}[\mathrm{eIF} 4 \mathrm{E}: 4 \mathrm{E}-\mathrm{BP}]+k_{\mathrm{off} 2}[\mathrm{eIF} 4 \mathrm{E}: \mathrm{eIF} 4 \mathrm{G}]$

$-k_{\text {on1 }}[\mathrm{eIF} 4 \mathrm{E}][4 \mathrm{E}-\mathrm{BP}]-k_{\mathrm{on} 2}[\mathrm{eIF} 4 \mathrm{E}][\mathrm{eIF} 4 \mathrm{G}]$

(2) $d[4 \mathrm{E}-\mathrm{BP}] / d t=k_{\text {off }}[\mathrm{eIF} 4 \mathrm{E}: 4 \mathrm{E}-\mathrm{BP}]+k_{\text {cat }}[\mathrm{mRNA} 4 \mathrm{E}-\mathrm{BP}][\mathrm{eIF} 4 \mathrm{E}: \mathrm{eIF} 4 \mathrm{G}]$

$$
-k_{\text {on1 }}[\mathrm{eIF} 4 \mathrm{E}][4 \mathrm{E}-\mathrm{BP}]-k_{\mathrm{lysis} 4 \mathrm{E}-\mathrm{BP}}[4 \mathrm{E}-\mathrm{BP}]
$$

(3) $d[\mathrm{eIF} 4 \mathrm{G}] / d t=k_{\mathrm{off} 2}[\mathrm{eIF} 4 \mathrm{E}: \mathrm{eIF} 4 \mathrm{G}]-k_{\mathrm{on} 2}[\mathrm{eIF} 4 \mathrm{E}][\mathrm{eIF} 4 \mathrm{G}]$

(4) $d[$ eIF4E:4E-BP $] / d t=k_{\text {on1 }}[\mathrm{eIF} 4 \mathrm{E}][4 \mathrm{E}-\mathrm{BP}]-k_{\mathrm{off} 1}[\mathrm{eIF} 4 \mathrm{E}: 4 \mathrm{E}-\mathrm{BP}]$

(5) $d[\mathrm{eIF} 4 \mathrm{E}: \mathrm{eIF} 4 \mathrm{G}] / d t=k_{\mathrm{on} 2}[\mathrm{eIF} 4 \mathrm{E}][\mathrm{eIF} 4 \mathrm{G}]-k_{\mathrm{off} 2}[\mathrm{eIF} 4 \mathrm{E}: \mathrm{eIF} 4 \mathrm{G}]$

(6a) $d[\mathrm{XXmRNAcyclinB]} / d t=-k a[\mathrm{XXmRNAcyclinB}]$

(6b) $d[\mathrm{XXmRNAcyclinBactive}] / d t=+k a[\mathrm{XXmRNAcyclinB}]$

(7) $d \alpha[\operatorname{Prot}] / d t=\alpha k_{\text {cat }}[$ mRNAProtein][eIF4E:eIF4G]

(8) $d \beta[$ cyclinB $] / d t=\beta k_{\text {cat }}[\mathrm{mRNAcyclinB}][\mathrm{eIF} 4 \mathrm{E}: \mathrm{eIF} 4 \mathrm{G}]$

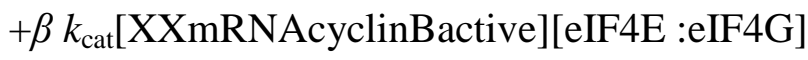

\section{Model reduction}

Assuming that the general amount of cyclin B mRNA is constant, the sum [XXmRNAcyclinB $]+[\mathrm{XXmRNAcyclinBactive}]$ is an invariant of the system. Therefore, equations (6b) and (8) can be reduced into a single equation:

(8) $d \beta[$ cyclinB $] / d t=\beta k_{\text {cat }}[\mathrm{mRNAcyclinB}][\mathrm{eIF} 4 \mathrm{E}: \mathrm{eIF} 4 \mathrm{G}]$

$+\beta k_{\text {cat }}\left([\mathrm{XXmRNAcyclinB}]_{0}-[\mathrm{XXmRNAcyclinB}]\right)[\mathrm{eIF} 4 \mathrm{E}: \mathrm{eIF} 4 \mathrm{G}]$

The next step was to simulate the model to determine if a set of parameters could be inferred that fit the experimental data; however, the system was under-determined 
with respect to available information on kinetic rates. We therefore focused on the inference of synthetic parameters, particularly on the ratio between pathway 1 and pathway 2 for cyclin B biosynthesis, which correspond to the ratio between mRNAcyclinB and XXmRNAcyclinBactive, and on the six parameters $\alpha, \beta, k_{a}, k_{c a t}$, $\delta$ (delay for full activation), and t(time interval from fertilization).

The following piecewise linear function was used to model the progressive changes of the kinetic parameters:

$$
f_{t 0, \delta}(t)=\left(t-t_{0}\right) / \delta \mathrm{II}_{[\mathrm{t} 0, \mathrm{t} 0+\delta]}(t)+\mathrm{I}_{\mathrm{j} t 0+\delta,+\infty[}(t)
$$

where $\mathrm{II}$ is the indicator function of the interval I (meaning that $\mathrm{I}_{\mathrm{I}}(t)=1$ if $t$ is in $\mathrm{I}$, otherwise $\left.\mathrm{I}_{\mathrm{I}}(t)=0\right)$. The function $f_{t 0, \delta}$ increases linearly from 0 to 1 between the instances $t_{0}$ and $t_{0}+\delta$. The following progressive changes of the parameters $k_{\text {off } 1}$, $\mathrm{k}_{\text {lys } 4 \mathrm{E}-\mathrm{BP}}$ (with parameters $\mathrm{t}_{1}, \delta_{1}$ ), and $\mathrm{k}_{\mathrm{a}}$ (with parameters $\mathrm{t}_{2}, \delta_{2}$ ) could then be used:

$$
\begin{gathered}
k_{\mathrm{off} 1}(t)=k_{\mathrm{off} 1 \min }+\left(k_{\mathrm{off} 1 \max }-k_{\mathrm{off} 1 \min }\right) f_{t 1, \delta 1}(t) \\
k_{\text {lysis4E-BP }}(t)=k_{\mathrm{lysis} 4 \mathrm{E}-\mathrm{BPmin}}+\left(k_{\mathrm{lysis} 4 \mathrm{E}-\mathrm{BP} \max }-k_{\mathrm{lysis} 4 \mathrm{E}-\mathrm{BP} \min }\right) f_{t 1, \delta 1}(t) \\
k_{a}(t)=k_{a} f_{t 2, \delta 2}(t)
\end{gathered}
$$

The change of $\mathrm{k}_{\mathrm{off} 1}$ starts immediately $\left(\mathrm{t}_{1}=0\right)$, whereas $\delta_{1}$ was estimated to be equal to 5 minutes (Laurent et al. 2014). The parameters $t_{2}$ and $\delta_{2}$ for $k_{a}$ have to be determined, so replacing $\mathrm{k}_{\mathrm{a}}$ by its value in the differential equation (6a) yields: 
$d[\mathrm{XXmRNAcyclinB}](t) / d t=-k_{a}\left(\left(t-t_{2}\right) / \delta_{2} \mathrm{II}_{[2, t 2+\delta 2]}(t)+\mathrm{II}_{] 2+\delta 2,+\infty[}(t)\right)[\mathrm{XXmRNAcyclinB}](t)$

This equation is solved on each interval $\left.\mathrm{I}_{1}=\right]-\infty, \mathrm{t}_{2}\left[, \mathrm{I}_{2}=\left[\mathrm{t}_{2}, \mathrm{t}_{2}+\delta_{2}\right]\right.$ and $\left.\mathrm{I}_{3}=\right] \mathrm{t}_{2}+\delta_{2},+\infty[$. In interval $I_{1}$, the concentration XXmRNAcyclinB is constant. In interval $I_{2}$,

$$
d[\mathrm{XXmRNAcyclinB}](t) / d t=-k_{a}\left(t-t_{2}\right) / \delta_{2}[\mathrm{XXmRNAcyclinB}](t)
$$

whose solution is:

$$
[\mathrm{XXmRNAcyclinB}](t)=[\mathrm{XXmRNAcyclinB}]_{0} \exp \left(-k_{a}\left(t-t_{2}\right)^{2} /\left(2 \delta_{2}\right)\right)
$$

$\ln I_{3}$, the following equation is verified as:

$$
d[\mathrm{XXmRNAcyclinB}](t) / d t=-k_{a}[\mathrm{XXmRNAcyclinB}](t)
$$

whose solution is:

$$
[\mathrm{XXmRNAcyclinB}](t)=[\mathrm{XXmRNAcyclinB}]_{0} \exp \left(-k_{a} \delta_{2} / 2\right) \exp \left(-k_{a}\left(t-t_{2}-\delta_{2}\right)\right)
$$

To sum up, the solution of equation (6a) is:

$$
[\mathrm{XXmRNAcyclinB}](t)=[\mathrm{XXmRNAcyclinB}]_{0} g_{k a, t 2, \delta 2}(t)
$$

with

$$
g_{k a, t 2, \delta 2}(t)=\mathrm{II}_{\mathrm{I} 1}(t)+\mathrm{II}_{\mathrm{I} 2}(t) \exp \left(-k_{a}\left(t-t_{2}\right)^{2} /\left(2 \delta_{2}\right)\right)+\mathrm{II}_{\mathrm{I} 3}(t) \exp \left(-k_{a} \delta_{2} / 2\right) \exp \left(-k_{a}\left(t-t_{2}-\delta_{2}\right)\right)
$$

As $[X X m R N A c y c l i n B]+[X X m R N A c y c l i n B a c t i v e]$ is constant, the solution for [XXmRNAcyclinBactive] can also be determined as: 
$[$ XXmRNAcyclinBactive $](t)=[\text { XXmRNAcyclinB }]_{0}\left(1-g_{k a, t 2, \delta 2}(t)\right)$

The differential equations of the model were transformed as follows:

(1) $d[\mathrm{eIF} 4 \mathrm{E}] / d t=k_{\text {off1 }}[\mathrm{eIF} 4 \mathrm{E}: 4 \mathrm{E}-\mathrm{BP}]+k_{\mathrm{off} 2}[\mathrm{eIF} 4 \mathrm{E}: \mathrm{eIF} 4 \mathrm{G}]-k_{\mathrm{on} 1}[\mathrm{eIF} 4 \mathrm{E}][4 \mathrm{E}-\mathrm{BP}]$

$$
\text { - } k_{\mathrm{on} 2}[\mathrm{eIF} 4 \mathrm{E}][\mathrm{e} I \mathrm{~F} 4 \mathrm{G}]
$$

(2) $d[4 \mathrm{E}-\mathrm{BP}] / d t=k_{\text {off }}[\mathrm{eIF} 4 \mathrm{E}: 4 \mathrm{E}-\mathrm{BP}]+\mathrm{P} 1[\mathrm{eIF} 4 \mathrm{E}: \mathrm{eIF} 4 \mathrm{G}]$

$$
-k_{\text {on1 }}[\mathrm{eIF} 4 \mathrm{E}][4 \mathrm{E}-\mathrm{BP}]-k_{\mathrm{lysis} 4 \mathrm{E}-\mathrm{BP}}[4 \mathrm{E}-\mathrm{BP}]
$$

(3) $d[\mathrm{eIF} 4 \mathrm{G}] / d t=k_{\mathrm{off} 2}[\mathrm{eIF} 4 \mathrm{E}: \mathrm{eIF} 4 \mathrm{G}]-k_{\mathrm{on} 2}[\mathrm{eIF} 4 \mathrm{E}][\mathrm{eIF} 4 \mathrm{G}]$

(4) $d[\mathrm{eIF} 4 \mathrm{E}: 4 \mathrm{E}-\mathrm{BP}] / d t=k_{\mathrm{on} 1}[\mathrm{eIF} 4 \mathrm{E}][4 \mathrm{E}-\mathrm{BP}]-k_{\mathrm{off}}[\mathrm{eIF} 4 \mathrm{E}: 4 \mathrm{E}-\mathrm{BP}]$

(5) $d[\mathrm{eIF} 4 \mathrm{E}: \mathrm{eIF} 4 \mathrm{G}] / d t=k_{\mathrm{on} 2}[\mathrm{eIF} 4 \mathrm{E}][\mathrm{eIF} 4 \mathrm{G}]-k_{\mathrm{off} 2}[\mathrm{eIF} 4 \mathrm{E}: \mathrm{eIF} 4 \mathrm{G}]$

(6a) $[X X m R N A c y c l i n B](t)=[X X m R N A c y c l i n B]_{0} g_{k a, t 2, \delta 2}(t)$

(6b) $[$ XXmRNAcyclinBactive $](t)=[\text { XXmRNAcyclinB }]_{0}\left(1-g_{k a, t, \delta 2}(t)\right)$

(7) $d \alpha[\operatorname{Prot}] / d t=$ P2[eIF4E:eIF4G]

(8) $d \beta\left[\right.$ cyclinB] $/ d t=\left(\mathrm{P} 3\right.$ [eIF4E :eIF4G] $\left.+\mathrm{P} 4\left(1-g_{k a, t 2, \delta 2}(t)\right)\right)$ [eIF4E :eIF4G]

with the different parameters defined as:

$$
\begin{aligned}
& \mathrm{P} 1=k_{\text {cat }}[\text { mRNA4E-BP }] \\
& \mathrm{P} 2=\alpha k_{\text {cat }}[\text { mRNAProtein }] \\
& \mathrm{P} 3=\beta k_{\text {cat }}[\text { mRNAcyclinB }] \\
& \mathrm{P} 4=\beta k_{\text {cat }}[\text { XXmRNAcyclinB }]_{0}
\end{aligned}
$$

These modifications offer the following advantage: The differential equation system can now be used for simulation without the necessity of knowing values for $\alpha$ and $\beta$, nor the absolute amounts of each mRNA. 
$\mathrm{P} 1=\mathrm{k}_{\text {cat }}[\mathrm{mRNA4E-BP}]$ was already determined as $\mathrm{k}_{\text {cat4E-BP }}$ (Laurent et al. 2014).

$\mathrm{P} 3 / \mathrm{P} 4=\beta \mathrm{k}_{\text {cat }}[\mathrm{mRNAcyclinB}] / \beta \mathrm{k}_{\text {cat }}[\mathrm{XXmRNAcyclinB}]_{0}$ corresponds to the ratio at time zero between the two forms of mRNA for cyclin B biosynthesis through pathway 1 and pathway 2 .

$\mathrm{P} 4 /(\mathrm{P} 3+\mathrm{P} 4)$ corresponds to the proportion of cyclin $\mathrm{B}$ mRNA in the XXmRNAcyclinB form.

$\mathrm{P} 3 /(\mathrm{P} 3+\mathrm{P} 4)$ corresponds to the ratio between cyclin $\mathrm{B}$ initial biosynthesis from cyclin B mRNA and final cyclin B biosynthesis. The rate of cyclin B biosynthesis from mRNAcyclinB can be directly determined from the experimental values in the first minutes of its synthesis.

When $\alpha=\beta, P 2 /(P 3+P 4)=[$ mRNAProtein $] /([m R N A c y c l i n B]+[X X m R N A c y c l i n B])$ and thus corresponds to the biosynthesis of a characteristic protein whose mRNA is at the same total concentration of that of cyclin B. The ratio of the slopes of a[Protein] and $\beta[$ cyclinB] fits on the same biosynthetic scale and tends to this value $P 2 /(P 3+P 4)$. We also considered the possibility that $\mathrm{k}_{\mathrm{cat}}$ for the XXmRNAcyclinB could be different from that of the other mRNAs; in this case, the Pi values will be the same.

\section{Simulations and parameters changes at fertilization.}

Simulations could now be performed using these differential equations in order to infer parameters $\mathrm{P} 1, \mathrm{P} 2, \mathrm{P} 3, \mathrm{P} 4, \mathrm{k}_{\mathrm{a}}, \mathrm{t}_{2}$, and $\delta_{2}$. Parameters for regulating the availability of elF4E for cap-dependent protein synthesis by the decrease in the protein regulator 4E-BP were previously determined, and total concentrations of elF4E, elF4G, and 4E-BP were previously measured (Laurent et al. 2014). Using 
these parameters, the present model leads to absolutely identical kinetics for elF4E, 4E-BP, elF4G, elF4E:4E-BP, elF4E:elF4G, and total 4E-BP (Laurent et al. 2014).

We first observed that $\delta_{2}$, corresponding to the delay necessary for full activation of $k_{a}$, was not a determinant parameter, so it was fixed to 5 minutes, as was $4 \mathrm{E}-\mathrm{BP}$ regulation. In contrast, $\mathrm{t}_{2}$, the time interval from fertilization for the activation of $k_{a}$, appeared highly sensitive.

The parameter P2 ( $\alpha \mathrm{k}_{\text {cat }}[\mathrm{mRNAProtein]}$ ) could be directly deduced from global protein biosynthesis kinetic. The best fit to the experimental data using a leastsquares adjustment method was obtained with $\mathrm{P} 2=27.43 \mathrm{sec}^{-1}$.

The best fit of parameters P3 ( $\left.\beta k_{\text {cat }}[m R N A c y c l i n B]\right), \quad P 4$ $\left(\beta k_{\text {cat }}[X X m R N A c y c l i n B]_{0}\right), k_{a}$, and $t_{2}$ was searched using a least-squares adjustment method of the simulated curves to the experimental data. A best fit was obtained with $\mathrm{P} 3=4.055 \mathrm{sec}^{-1}, \mathrm{P} 4=80.111 \mathrm{sec}^{-1}, \mathrm{k}_{\mathrm{a}}=0.02388 \mathrm{sec}^{-1}$, and $\mathrm{t}_{2}=2527 \mathrm{sec}(42 \mathrm{~min})$. The optimal distance in the least-squares determination was 0.0006645 . The values are not impacted in the case of a different $k_{\text {cat }}$ value for the translation of XXmRNAcyclinB. P3/P4 $=0.05$ indicated that $5 \%$ of cyclin B mRNA in the unfertilized egg would be immediately available for cyclin B synthesis, whereas $95 \%$ would be in the non-available XXmRNAcyclinB form.

Figure 5 illustrates how the simulated curves observed with the best-fitting parameters predict the experimental values for both global proteins and cyclin B. The contribution to total cyclin B synthesis from the two pathways, mRNAcyclinB (pathway1) and XXmRNAcyclinB (pathway2), is also shown.

\section{Sensitivity of the parameters}


Each of the parameters $\mathrm{P} 3, \mathrm{P} 4, \mathrm{k}_{\mathrm{a}}$, and $\mathrm{t}_{2}$ were fixed at value intervals from $5 \%$ to $+5 \%$ of the best-fitting values. The minimal square value was calculated and plotted for each of the 20 intervals selected for each parameter (Fig. 6), and a confidence interval was determined for each parameter in the $5 \%$ limit of the distance from the best-fitting value. P3 values ranged from 0 to $14 \mathrm{sec}^{-1} ; \mathrm{P} 4$ from 68 to $89 \mathrm{sec}^{-}$ ${ }^{1} ; \mathrm{k}_{\mathrm{a}}$ from $0.003 \mathrm{sec}^{-1}$ to infinity; and $\mathrm{t}_{2}$ from 33 to 47 minutes (Fig. 6). The best-fitting $k_{a}$ value was $0.029 \mathrm{sec}^{-1}$, but largely varied for increasing values without substantial influence on the global fit. The minimum value for $k_{a}$ is mathematically at least 0.003 $\sec ^{-1}$, but has no significant maximum value. We performed many simulations using a range of $k_{a}$ values: Increasing $k_{a}$ values sharpened the timing between first (0-35 minutes) and second (45-90 minutes) cyclin B synthesis phases without changing the slopes of the curves. Regarding the values of P3 and P4, the deduced ratio of mRNAcyclinB versus XXmRNAcyclinB would mathematically range between 0 and $15.6 \%$, with a best-fit value of 4.82 , showing that the biosynthesis of cyclin B through pathway 2 is dominant over pathway 1 . The time interval for $k_{a}$ activation (42 minutes) appears to be an important, reliable determination from the simulations.

P3 and P4 may be linked, so we generated a heat map of their relationship (Fig. 7). The best fit, judged as the minimal square difference between calculated and experimental points, was computed for 20 values of both $\mathrm{P} 3$ and $\mathrm{P} 4$ parameters with $k_{a}$ and $t_{2}$ at their optimum value. The results were plotted as a heat-map curve. The best-fit values tracked along a line, with P4 increasing when P3 decreased. The highest P3 values influence the first slope of the simulation curve, while a decrease in P4 value may compensate to maintain the second slope of the curve.

\section{Discussion}


Much experimental data regarding the biosynthesis of proteins and the specific synthesis of cyclin B following fertilization in sea urchin eggs originated from many measurements made in the laboratory. Direct comparison between both sets of experimental results was never possible because no quantitative data on the absolute amounts of the measured proteins were available. The present analysis instead focused on the analysis of the kinetic profiles of the two independent sets of data. The objective was to compare the kinetics of cyclin B biosynthesis to the majority of other de novo-synthetized proteins, and to obtain parameters that fit the experimental observations, which would allow for experimental predictions in future experiments.

A model was built on the parsimony principle regarding the number of components involved - i.e. with the minimal number of parameters that would be necessary to fit the experimental data. The parsimonious model constructed took advantage of one major biological pathway for protein synthesis in eukaryotic cells, known as the cap-dependent pathway, which is directly reliant on the amount of initiation complex elF4E:elF4G and the amount of mRNA available for each protein; the constant for such reactions was called $\mathrm{k}_{\text {cat }}$. Synthesis of each individual protein at fertilization could be assumed to be directly proportional to elF4E:eIF4G and to the concentration of each mRNA in the sea urchin egg for two reasons: First, the capdependent pathway was predominant, including for synthesis of cyclin B, as judged from specific inhibition experiments of cap-dependent translation (Chasse et al. 2016). Second, the early steps of translation in the sea urchin zygote take place from maternal mRNAs, and are thus independent of transcription. The measured profile of cyclin B synthesis does not match the profile of global protein synthesis, so the mRNA for cyclin B was divided into two forms: one immediately available for cap- 
dependent translation and one not immediately available (XXmRNA); both forms are present in unfertilized eggs because transcription is not necessary for the first cell cycle. At fertilization, we assume that the XXmRNA becomes active and available for translation via a pathway not yet identified.

Using an original combination of parameters in the differential equations, we were able to compare the post-fertilization kinetic profiles of cyclin B biosynthesis to other proteins. The combination was $\mathrm{P} 1=\mathrm{k}_{\mathrm{cat}}[\mathrm{mRNA4E}-\mathrm{BP}] ; \quad \mathrm{P} 2=$ $\alpha \mathrm{k}_{\text {cat }}[\mathrm{mRNAProtein}] ; \quad \mathrm{P} 3=\quad \beta \mathrm{k}_{\text {cat }}[\mathrm{mRNAcyclinB}] ; \quad \mathrm{P} 4=\quad \beta \mathrm{k}_{\text {cat }}[\mathrm{XXmRNAcyclinB}]_{0}$. Introducing coefficients $\alpha$ and $\beta$, used to fit the respective different scales of the measurements, combined with the unknown concentrations of respective mRNAs, enabled determination of the kinetic constant $k_{a}$ for activation of cyclin B mRNA, which was at least equal to $0.0030 \mathrm{sec}^{-1}$ and optimal at $0.02388 \mathrm{sec}^{-1}$; whatever biological mechanism is responsible for this activation likely acts within this short period. Our approach also allowed us to determine that its activation is delayed until 42 minutes after fertilization, when a predominant proportion of cyclin B mRNA is activated.

The two pathways hypothesized for cyclin B entry into the translation machinery may help maintain low cyclin B levels in unfertilized eggs, to restrict the accumulation of cyclin B before fertilization, while ensuring rapid post-fertilization accumulation of the protein, for the formation and activation of the CDK1:cyclin B complex necessary for the fine tuning of cell cycle control. Several mechanisms that regulate these two pathways could be proposed. For example, XXmRNAcyclinB could be restricted in a cell compartment, as reported for maternal histone mRNAs, which are sequestered in the nucleus until its membrane breaks down (Showman et al. 1982). Nuclear sequestration is unlikely since cyclin B mRNA accumulates 
substantially prior to nuclear envelope breakdown (see Fig. 1), whereas changes in cytoplasmic localization, which should make the mRNA available for translation, is a possibility. Another hypothesis involves the formation of a complex between cyclin B mRNA and a regulatory protein, such as a functional analog of Cytoplasmic Polyadenylation Element Binding protein (CPEB), first identified in Xenopus oocytes at maturation (Hake and Richter 1994). CPEB binds to a family of mRNAs in eukaryotic cells, controlling their entry in the translation machinery. mRNAs bound to CPEB are released for translation upon phosphorylation of CPEB (Mendez et al. 2002), which displaces the protein maskin from the polyadenylation sequence, thus allowing polymerization of the Poly $A$ tail that recruits translational machinery via polyadenylate-binding protein (PABP) (Ivshina et al. 2014). Although CPEB proteins may exist in sea urchin, based on the presence of the gene in the genome (Morales et al. 2006), there is yet no experimental evidence for CPEB regulation at fertilization. Furthermore, maskin is not present in the sea urchin (Morales et al. 2006). Nevertheless, a mechanism that similarly regulates the availability of mRNA may exist in the sea urchin; if so, the $\mathrm{k}_{\mathrm{a}}$ of the mRNA bound to this unidentified protein would have to be at least $0.003 \mathrm{sec}^{-1}$, and its inactivation should occur around 40 minutes after fertilization.

Other models, based on gene-specific translation, could be built. A unique mRNA for cyclin B is one example. Such a model would necessitate a change in the $\mathrm{k}_{\text {cat }}$ of cyclin B, from a low value in unfertilized eggs, to explain the presence of maternal cyclin $B$, to a high value, to fit with the increase observed after fertilization. In this proposal, $\mathrm{k}_{\mathrm{a}}$ would correspond to the activation parameter $\mathrm{k}_{\mathrm{cat}}$-cyclin $\mathrm{B}$. Importantly, the delay and activation time $\left(\mathrm{k}_{\mathrm{a}}\right)$ between the low to the high value of $\mathrm{k}_{\text {cat }}$-Cyclin B would have to be the same. Instead of the ratio between two mRNAs for 
cyclin $\mathrm{B}$, the fraction (P3/P4) of available mRNA would become the fraction of highto-low values of $\mathrm{k}_{\mathrm{cat}}$-cyclin $\mathrm{B}$ for the translation of a unique cyclin B mRNA. However, a model keeping $\mathrm{k}_{\text {cat }}$ constant for all individual mRNAs, including mRNAs for cyclin $\mathrm{B}$, is preferred since all mRNAs enter the same cap-dependent translational machinery (Chassé et al, 2016)

Several scenarios could have been used to build the model. We chose one using parsimony principle that is compatible with the biological data. The model generated simulated the biological observations, and provided predictions for further empirical experiments. The originality of the mathematical derivations circumvents the gaps in the biological data (no absolute values and different scale determinations), but still allows for the input of data when these become available. The model can also be used for deciding how "wet" experiments should be conducted to definitively identify the molecular mechanisms responsible for cyclin B translational control.

The translation of proteins, like heat-shock protein 90 (Hsp90) and actin, are also reported to be delayed after fertilization (Bedard and Brandhorst 1986). Conversely, the small subunit of ribonucleotide reductase appears to be actively translated soon after sea urchin fertlization (Standart et al. 1985). Comparison of each of these proteins to that of the de novo synthesis of cyclin B would be interesting, when experimentally possible, as it might help reveal how gene-specific mRNAs are translationally controlled.

\section{Material and Methods}

\section{Handling of gametes and embryos}

Sphaerechinus granularis sea urchins, collected in the Brest area (France), 
were maintained in running seawater at Centre de Ressources Biologiques Marines (CRBM) in the Roscoff Biological Station. Spawning of gametes, fertilization, and cell culture were as described (Marc et al. 2002; Oulhen et al. 2010). Experiments were only performed on batches exhibiting greater than $90 \%$ fertilization and activation. Each experiment used gametes from a single female.

\section{Determination of protein synthesis in vivo}

Unfertilized eggs ( $5 \%$ suspension in filtered seawater) were incubated for 1 hour in the presence of $10 \mu \mathrm{Ci} / \mathrm{ml}\left[{ }^{35} \mathrm{~S}\right]-\mathrm{L}$-methionine (Perkin Elmer). Eggs were then harvested by centrifugation, rinsed three times, re-suspended in fresh seawater, and fertilized. Batches $(500 \mu \mathrm{L})$ of the zygote suspension were taken at different times, and then pelleted and frozen in liquid nitrogen.

For pulse labeling experiments, eggs ( $5 \%$ suspension in filtered seawater) were fertilized and cultured at $16^{\circ} \mathrm{C}$ under constant agitation. Every 15 minutes, batches of zygotes $(500 \mu \mathrm{L})$ were pulse-labeled for 10 minutes with $10 \mu \mathrm{Ci} / \mathrm{ml}\left[{ }^{35} \mathrm{~S}\right]-\mathrm{L}$ methionine. After rinsing in filtered seawater, zygotes were pelleted and frozen in liquid nitrogen.

Soluble protein extracts $(13,000 \mathrm{~g}$ supernatants) were prepared as previously described (Marc et al. 2002; Oulhen et al. 2010). Total ${ }^{35}$ S]-L-methionine uptake was determined on duplicate aliquots of the extract. $\left[{ }^{35} \mathrm{~S}\right]-\mathrm{L}-$ methionine incorporation into proteins was measured on duplicate aliquots after 10\% trichloroacetic acid precipitation on Whatman 3M filters (GEHealthcare). Radioactivity was counted in the presence of Optiphase Supermix scintillation liquid (Perkin Elmer). The results, expressed in arbitrary units, correspond to the percentage of $\left[{ }^{35} \mathrm{~S}\right]$-L-methionine incorporated into proteins over total radioactivity recovered in the cells. Radioactive 
proteins were visualized after resolution of the proteins from an aliquot of each supernatant on $12 \%$ acrylamide SDS gels, followed by autoradiography on Kodak Biomax MR film (Sigma).

\section{Determination of cyclin B synthesis in vivo}

Cyclin B synthesis was measured using two independent protocols, one involving cyclin B purification from $\left[{ }^{35} \mathrm{~S}\right]-\mathrm{L}$-methionine labeled extracts and the other by immunoblotting total egg extracts.

De novo-synthesized cyclin B was quantified after affinity purification of the whole CDK1/cyclin B complex on p13suc1-Sepharose beads, as previously described (Marc et al. 2002). Briefly, soluble extracts from $\left[{ }^{35} \mathrm{~S}\right]-\mathrm{L}-\mathrm{methionine-labeled}$ embryos, as described above, were prepared at different times following fertilization. Protein bound to p13suc1-Sepharose beads was recovered and resolved by $12 \%$ acrylamide SDS gels. Labeled bands were revealed by autoradiography on Kodak Biomax MR film (Sigma) and quantified after digitization of the films using ImageJ software (National Institutes of Health, Bethesda, MD, USA).

Total cyclin B abundance was quantified by immnoblotting total extracts of embryos at different times following fertilization, as previously reported (Chassé et al, 2016). Briefly, solubilized proteins were resolved by SDS gel electrophoresis (12\% acrylamide/ $0.1 \%$ bisacrylamide gels) and transferred onto nitrocellulose membranes. Cyclin B was immunodetected with rabbit polyclonal antibodies directed against $S$. granularis cyclin B (Lozano et al. 1998), a generous gift from Professor Gérard Peaucellier (Banyuls, France). The antigen-antibody complex was detected and quantified as previously reported (Chasse et al. 2016) 


\section{Programming, calculations, and graphical framework representation}

The programming, simulations, and calculations were performed using the Python package Scipy (Olivier et al. 2002; Perez and Granger 2007; Ekmekci et al. 2016). Cytoscape software for integrated models of biomolecular interaction networks (Shannon et al. 2003) was used to generate the reaction graph of the model.

\section{Author contributions}

VP did all the mathematic analysis and the computing. RB designed and coordinated the study. All authors contributed to the model elaboration and to the analysis of the results.

\section{References}

Bedard PA, Brandhorst BP. 1986. Translational activation of maternal mRNA encoding the heat-shock protein hsp90 during sea urchin embryogenesis. Developmental biology 117(1):286-293 .

Belle R, Prigent S, Siegel A, Cormier P. 2010. Model of cap-dependent translation initiation in sea urchin: a step towards the eukaryotic translation regulation network. Molecular reproduction and development 77(3):257-264.

Brandhorst BP. 1976. Two-dimensional gel patterns of protein synthesis before and after fertilization of sea urchin eggs. Developmental biology 52(2):310-317.

Brandhorst BP. 1980. Simultaneous synthesis, translation, and storage of mRNA including histone mRNA in sea urchin eggs. Developmental biology 79(1):139148.

Chasse H, Mulner-Lorillon O, Boulben S, Glippa V, Morales J, Cormier P. 2016. Cyclin B Translation Depends on mTOR Activity after Fertilization in Sea Urchin Embryos. PloS one 11(3):e0150318.

Cormier P, Chasse H, Cosson B, Mulner-Lorillon O, Morales J. 2016. Translational control in echinoderms: the calm before the storm. In: Hernandez G, Jagus R, editors. Evolution of the protein synthesis machinery and its regulation: Springer International Publishing (Verlag). p pp 413-434.

Cormier P, Pyronnet S, Morales J, Mulner-Lorillon O, Sonenberg N, Belle R. 2001. elF4E association with 4E-BP decreases rapidly following fertilization in sea urchin. Developmental biology 232(2):275-283.

Cormier P, Pyronnet S, Salaun P, Mulner-Lorillon O, Sonenberg N. 2003. Capdependent translation and control of the cell cycle. Progress in cell cycle research 5:469-475. 
Dube F. 1988. Effect of reduced protein synthesis on the cell cycle in sea urchin embryos. Journal of cellular physiology 137(3):545-552.

Ekmekci B, McAnany CE, Mura C. 2016. An Introduction to Programming for Bioscientists: A Python-Based Primer. PLoS computational biology 12(6):e1004867.

Epel D. 1967. Protein synthesis in sea urchin eggs: a "late" response to fertilization. Proceedings of the National Academy of Sciences of the United States of America 57(4):899-906.

Epel D. 1990. The initiation of development at fertilization. Cell differentiation and development : the official journal of the International Society of Developmental Biologists 29(1):1-12.

Evans T, Rosenthal ET, Youngblom J, Distel D, Hunt T. 1983. Cyclin: a protein specified by maternal mRNA in sea urchin eggs that is destroyed at each cleavage division. Cell 33(2):389-396.

Fraser CS. 2009. The molecular basis of translational control. Progress in molecular biology and translational science 90:1-51.

Gilbert SF. 2013. Sea urchins and Tunicates. In: Gilbert SF, editor. Developmental biology. Sunderland (MA): Sinauer Associates, Inc. p 217-240.

Gross PR, Cousineau GH. 1963. Effects of actinomycin D on macromolecule synthesis and early development in sea urchin eggs. Biochemical and biophysical research communications 10:321-326.

Haghighat A, Mader S, Pause A, Sonenberg N. 1995. Repression of cap-dependent translation by 4E-binding protein 1: competition with p220 for binding to eukaryotic initiation factor-4E. The EMBO journal 14(22):5701-5709.

Hake LE, Richter JD. 1994. CPEB is a specificity factor that mediates cytoplasmic polyadenylation during Xenopus oocyte maturation. Cell 79(4):617-627.

Hershey JW, Sonenberg N, Mathews MB. 2012. Principles of translational control: an overview. In: Hershey JWB, Sonenberg N, Mathews MB, editors. Protein synthesis and translational control. New York: CSHL p1-10.

Hinnebusch AG, Ivanov IP, Sonenberg N. 2016. Translational control by 5'untranslated regions of eukaryotic mRNAs. Science 352(6292):1413-1416.

Hunt T. 2002. Nobel Lecture. Protein synthesis, proteolysis, and cell cycle transitions. Bioscience reports 22(5-6):465-486.

Ivshina M, Lasko P, Richter JD. 2014. Cytoplasmic polyadenylation element binding proteins in development, health, and disease. Annual review of cell and developmental biology 30:393-415.

Jackson RJ, Hunt SL, Reynolds JE, Kaminski A. 1995. Cap-dependent and capindependent translation: operational distinctions and mechanistic interpretations. Current topics in microbiology and immunology 203:1-29.

Komar AA, Mazumder B, Merrick WC. 2012. A new framework for understanding IRES-mediated translation. Gene 502(2):75-86.

Laurent S, Richard A, Mulner-Lorillon O, Morales J, Flament D, Glippa V, Bourdon J, Gosselin P, Siegel A, Cormier P, Belle R. 2014. Modelization of the regulation of protein synthesis following fertilization in sea urchin shows requirement of two processes: a destabilization of elF4E:4E-BP complex and a great stimulation of the 4E-BP-degradation mechanism, both rapamycin-sensitive. Frontiers in genetics 5:117.

Liu Y, Beyer A, Aebersold R. 2016. On the Dependency of Cellular Protein Levels on mRNA Abundance. Cell 165(3):535-550. 
Lozano JC, Schatt P, Marques F, Peaucellier G, Fort P, Feral JP, Geneviere AM, Picard A. 1998. A presumptive developmental role for a sea urchin cyclin B splice variant. The Journal of cell biology 140(2):283-293.

Mader S, Lee H, Pause A, Sonenberg N. 1995. The translation initiation factor elF-4E binds to a common motif shared by the translation factor elF-4 gamma and the translational repressors 4E-binding proteins. Molecular and cellular biology 15(9):4990-4997.

Malumbres M. 2014. Cyclin-dependent kinases. Genome biology 15(6):122.

Marc J, Mulner-Lorillon O, Boulben S, Hureau D, Durand G, Belle R. 2002. Pesticide Roundup provokes cell division dysfunction at the level of CDK1/cyclin $B$ activation. Chemical research in toxicology 15(3):326-331.

Mathews MB, Sonenberg N, Hershey J. 2007. Origine and and principles of translational control In: Sonenberg $\mathrm{N}$, Hershey J, Mathews $\mathrm{M}$, editors. Translational control in Biology and Medecine. New York: CSHL press. p 1-31.

Mendez R, Barnard D, Richter JD. 2002. Differential mRNA translation and meiotic progression require Cdc2-mediated CPEB destruction. The EMBO journal 21(7):1833-1844.

Morales J, Mulner-Lorillon O, Cosson B, Morin E, Belle R, Bradham CA, Beane WS, Cormier P. 2006. Translational control genes in the sea urchin genome. Developmental biology 300(1):293-307.

Murray AW. 2004. Recycling the cell cycle: cyclins revisited. Cell 116(2):221-234.

Olivier BG, Rohwer JM, Hofmeyr JH. 2002. Modelling cellular processes with Python and Scipy. Molecular biology reports 29(1-2):249-254.

Oulhen N, Mulner-Lorillon O, Cormier P. 2010. elF4E-binding proteins are differentially modified after ammonia versus intracellular calcium activation of sea urchin unfertilized eggs. Molecular reproduction and development 77(1):83-91.

Oulhen N, Salaun P, Cosson B, Cormier P, Morales J. 2007. After fertilization of sea urchin eggs, elF4G is post-translationally modified and associated with the cap-binding protein elF4E. Journal of cell science 120(Pt 3):425-434.

Parrington J, Davis LC, Galione A, Wessel G. 2007. Flipping the switch: how a sperm activates the egg at fertilization. Developmental dynamics : an official publication of the American Association of Anatomists 236(8):2027-2038.

Perez F, Granger BE. 2007. IPython: A System for Interactive Scientific Computing. Computing in Science \& Engineering 9(3):21-29.

Salaun P, Boulben S, Mulner-Lorillon O, Belle R, Sonenberg N, Morales J, Cormier P. 2005. Embryonic-stage-dependent changes in the level of elF4E-binding proteins during early development of sea urchin embryos. Journal of cell science 118(Pt 7):1385-1394.

Salaun P, Le Breton M, Morales J, Belle R, Boulben S, Mulner-Lorillon O, Cormier P. 2004. Signal transduction pathways that contribute to CDK1/cyclin B activation during the first mitotic division in sea urchin embryos. Experimental cell research 296(2):347-357.

Salaun P, Pyronnet S, Morales J, Mulner-Lorillon O, Belle R, Sonenberg N, Cormier $P$. 2003. elF4E/4E-BP dissociation and 4E-BP degradation in the first mitotic division of the sea urchin embryo. Developmental biology 255(2):428-439.

Shannon P, Markiel A, Ozier O, Baliga NS, Wang JT, Ramage D, Amin N, Schwikowski B, Ideker T. 2003. Cytoscape: a software environment for integrated models of biomolecular interaction networks. Genome research 13(11):2498-2504. 
Showman RM, Wells DE, Anstrom J, Hursh DA, Raff RA. 1982. Message-specific sequestration of maternal histone mRNA in the sea urchin egg. Proceedings of the National Academy of Sciences of the United States of America 79(19):5944-5947.

Sodergren E, Weinstock GM, Davidson EH, Cameron RA, Gibbs RA, Angerer RC, Angerer LM, Arnone MI, Burgess DR, Burke RD, Coffman JA, Dean M, Elphick MR, Ettensohn CA, Foltz KR, Hamdoun A, Hynes RO, Klein WH, Marzluff W, McClay DR, Morris RL, Mushegian A, Rast JP, Smith LC, Thorndyke MC, Vacquier VD, Wessel GM, Wray G, Zhang L, Elsik CG, Ermolaeva O, Hlavina W, Hofmann G, Kitts P, Landrum MJ, Mackey AJ, Maglott D, Panopoulou G, Poustka AJ, Pruitt K, Sapojnikov V, Song X, Souvorov A, Solovyev V, Wei Z, Whittaker CA, Worley K, Durbin KJ, Shen Y, Fedrigo O, Garfield D, Haygood R, Primus A, Satija R, Severson T, GonzalezGaray ML, Jackson AR, Milosavljevic A, Tong M, Killian CE, Livingston BT, Wilt FH, Adams N, Belle R, Carbonneau S, Cheung R, Cormier P, Cosson B, Croce J, Fernandez-Guerra A, Geneviere AM, Goel M, Kelkar H, Morales J, Mulner-Lorillon O, Robertson AJ, Goldstone JV, Cole B, Epel D, Gold B, Hahn ME, Howard-Ashby M, Scally M, Stegeman JJ, Allgood EL, Cool J, Judkins KM, McCafferty SS, Musante AM, Obar RA, Rawson AP, Rossetti BJ, Gibbons IR, Hoffman MP, Leone A, Istrail S, Materna SC, Samanta MP, Stolc V, Tongprasit W, Tu Q, Bergeron KF, Brandhorst BP, Whittle J, Berney K, Bottjer DJ, Calestani C, Peterson K, Chow E, Yuan QA, Elhaik E, Graur D, Reese JT, Bosdet I, Heesun S, Marra MA, Schein J, Anderson MK, Brockton V, Buckley KM, Cohen AH, Fugmann SD, Hibino T, Loza-Coll M, Majeske AJ, Messier C, Nair SV, Pancer Z, Terwilliger DP, Agca C, Arboleda E, Chen N, Churcher AM, Hallbook F, Humphrey GW, Idris MM, Kiyama T, Liang S, Mellott D, Mu X, Murray G, Olinski RP, Raible F, Rowe M, Taylor JS, Tessmar-Raible K, Wang D, Wilson KH, Yaguchi S, Gaasterland T, Galindo BE, Gunaratne HJ, Juliano C, Kinukawa M, Moy GW, Neill AT, Nomura M, Raisch M, Reade A, Roux MM, Song JL, Su YH, Townley IK, Voronina E, Wong JL, Amore G, Branno M, Brown ER, Cavalieri V, Duboc V, Duloquin L, Flytzanis C, Gache C, Lapraz F, Lepage T, Locascio A, Martinez P, Matassi G, Matranga V, Range R, Rizzo F, Rottinger E, Beane W, Bradham C, Byrum C, Glenn T, Hussain S, Manning G, Miranda E, Thomason R, Walton K, Wikramanayke A, Wu SY, Xu R, Brown CT, Chen L, Gray RF, Lee PY, Nam J, Oliveri P, Smith J, Muzny D, Bell S, Chacko J, Cree A, Curry S, Davis C, Dinh H, Dugan-Rocha S, Fowler J, Gill R, Hamilton C, Hernandez J, Hines S, Hume J, Jackson L, Jolivet A, Kovar C, Lee S, Lewis L, Miner G, Morgan M, Nazareth LV, Okwuonu G, Parker D, Pu LL, Thorn R, Wright R. 2006. The genome of the sea urchin Strongylocentrotus purpuratus. Science 314(5801):941-952.

Sonenberg N, Gingras AC. 1998. The mRNA 5' cap-binding protein elF4E and control of cell growth. Current opinion in cell biology 10(2):268-275.

Standart NM, Bray SJ, George EL, Hunt T, Ruderman JV. 1985. The small subunit of ribonucleotide reductase is encoded by one of the most abundant translationally regulated maternal RNAs in clam and sea urchin eggs. The Journal of cell biology 100(6):1968-1976.

Wagenaar EB. 1983. The timing of synthesis of proteins required for mitosis in the cell cycle of the sea urchin embryo. Experimental cell research 144(2):393403. 
Wek RC. 1994. elF-2 kinases: regulators of general and gene-specific translation initiation. Trends in biochemical sciences 19(11):491-496.

Wilt FH. 1970. The acceleration of ribonucleic acid synthesis in cleaving sea urchin embryos. Developmental biology 23(3):444-455.

Young SK, Wek RC. 2016. Upstream Open Reading Frames Differentially Regulate Gene-specific Translation in the Integrated Stress Response. J Biol Chem 291(33):16927-16935.

Zhao YB, Krishnan J. 2015. Probabilistic Boolean Modeling and Analysis Framework for mRNA translation. IEEE/ACM transactions on computational biology and bioinformatics / IEEE, ACM. 


\section{Legend to figures}

Figure 1. Kinetics of de novo global protein versus cyclin B synthesis after fertilization.

Global protein synthesis and cyclin B synthesis were determined from independent experiments using 6 to 8 different sea urchin pairs of parents. Embryo culture was performed at $16^{\circ} \mathrm{C}$. Mean time of occurrence of nuclear envelope breakdown (NEBD) and cytokinesis are indicated (black bars). Values at time points, ranging up to 3 hours after fertilization for global proteins and up to the maximal level of cyclin B during the first cell division, are shown in arbitrary units as a function of time after fertilization, and were scaled for comparison for a mean protein at 60 minutes (relative to the same incorporation of $\left[{ }^{35} \mathrm{~S}\right]-$ methionine into cyclin $\mathrm{B}$ ) (arrowed).

Figure 2. Electophoretic pattern of proteins synthetized after fertilization.

Egg extracts were prepared from $\left[{ }^{35} \mathrm{~S}\right]$-methionine-loaded eggs at different times after fertilization, and subjected to electrophoresis and autoradiography. The migration position of cyclin B is indicated by an arrow.

Figure 3. Rate of protein synthesis following fertilization. The rate of protein synthesis determined by $\left[{ }^{35} \mathrm{~S}\right]-$ methionine pulse experiments. Each determination was performed at the indicated time after fertilization. The values from 13 independent experiments \pm standard error are indicated in arbitrary units. 
Figure 4. Reaction graph of the model. The reaction graph was generated using the Cytoscape software. Reactions and components are drawn in blue. The synthetized proteins are shown in green, with the two pathways for cyclin B synthesis.

Figure 5. Simulation of protein and cyclin B synthesis after fertilization using the bestfit parameters determined from the model. The experimental values are indicated on the simulation curves. The red curve corresponds to the synthesis of cyclin B from mRNAcyclinB (pathway 1). The green curve corresponds to the synthesis of cyclin B from the activated XXmRNAcyclinB (pathway 2). The sum of both is shown in purple.

Figure 6. Sensitivity of the model parameters. Each parameter was analyzed at value intervals from $-5 \%$ to $+5 \%$ of the best-fit value. The least-squares value was calculated from 20 intervals of the indicated parameter, and plotted in comparison to the original best-fit value (red line).

Figure 7. Heat-map of best-fit values when varying P3 and P4 parameters of the model. Least-squares values for P3 $\left(\beta \mathrm{k}_{\text {cat }}[\mathrm{mRNAcyclinB}]\right)$ and P4 $\left(\beta \mathrm{k}_{\text {cat }}[\mathrm{XXmRNAcyclinB}]_{0}\right)$ varying from their best-fit values (white $\mathrm{x}$ ) with other parameters maintained at their best-fit values. 


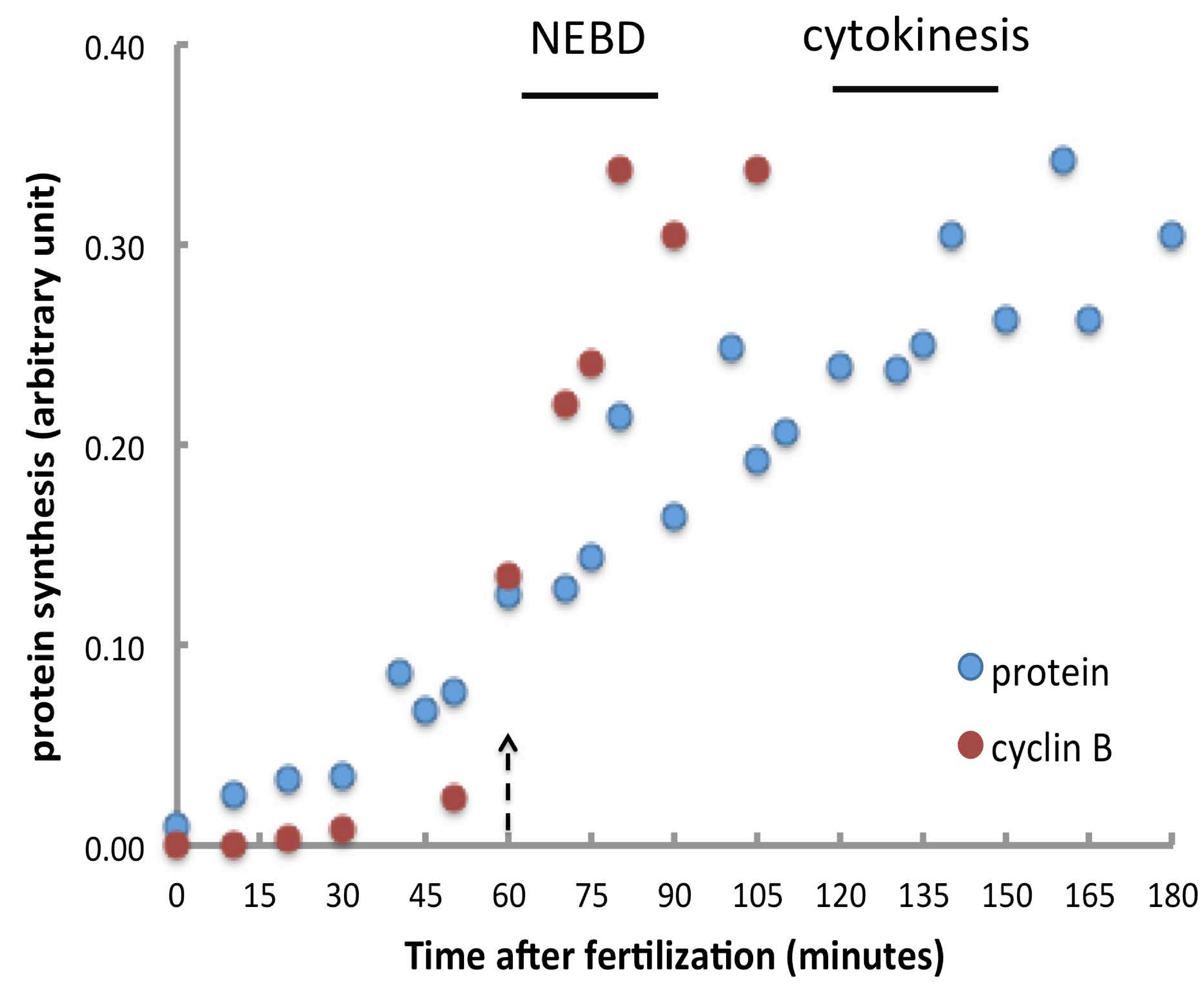

Fig.1. 
Time (minutes)

$\mathrm{kDa}$

$\begin{array}{lllllll}0 & 15 & 30 & 45 & 60 & 90 & 120\end{array}$

175

80

58.

$46 \circ$

30 -

$25 \circ$

17

Fig.2.

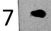




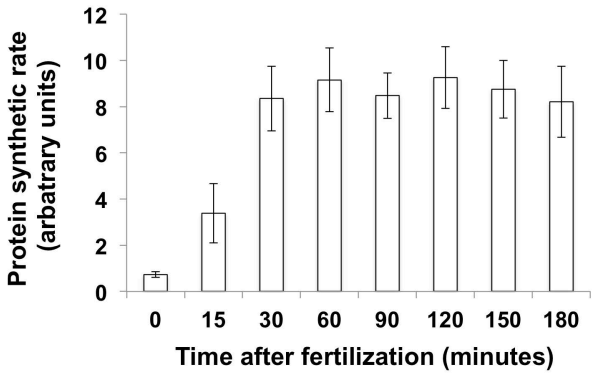

Fig.3. 


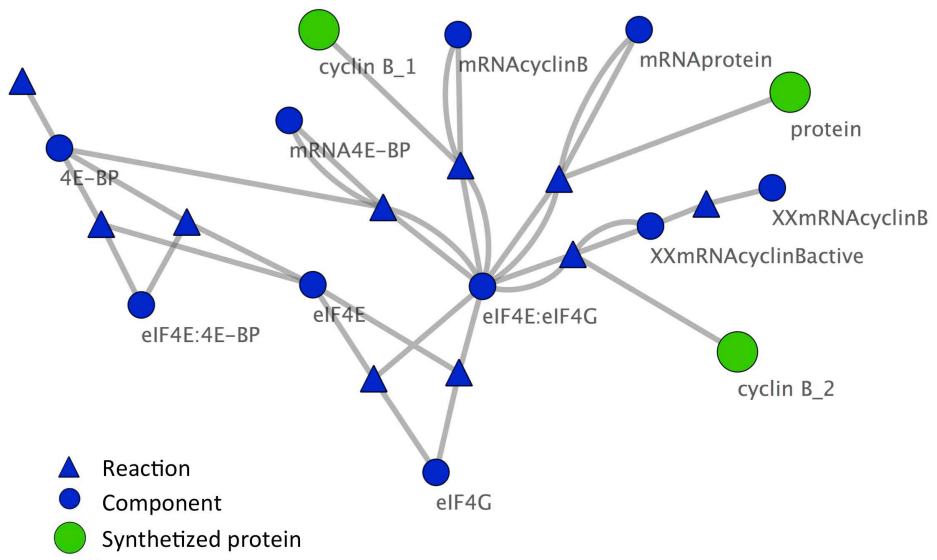

Fig. 4 . 


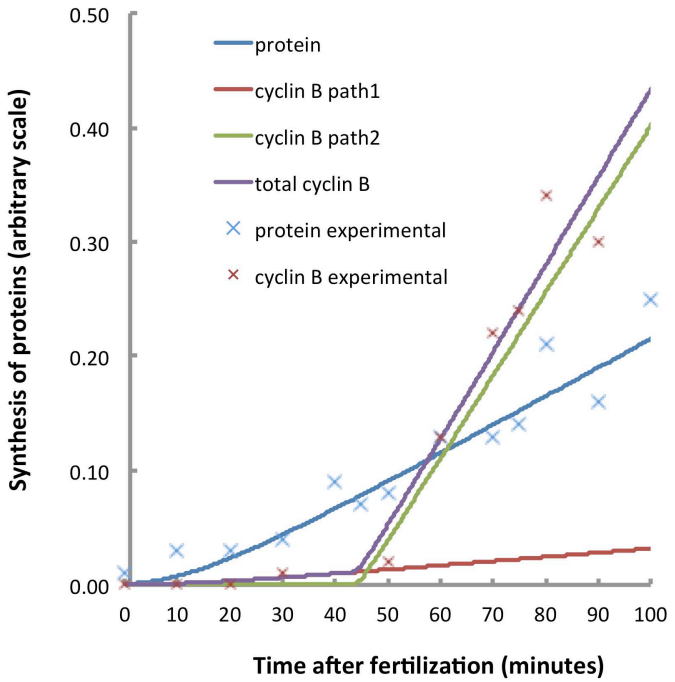

Fig. 5. 

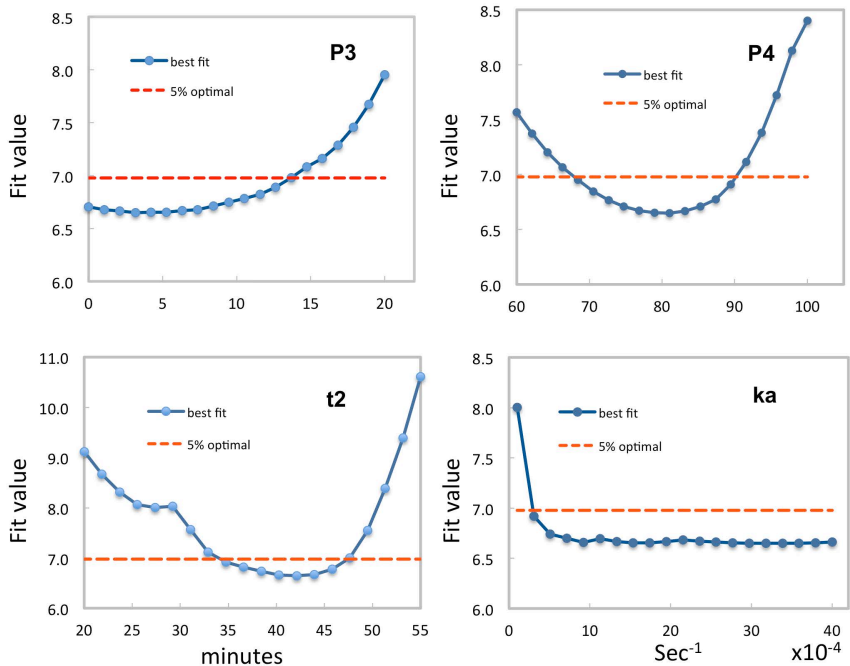

Fig.6. 


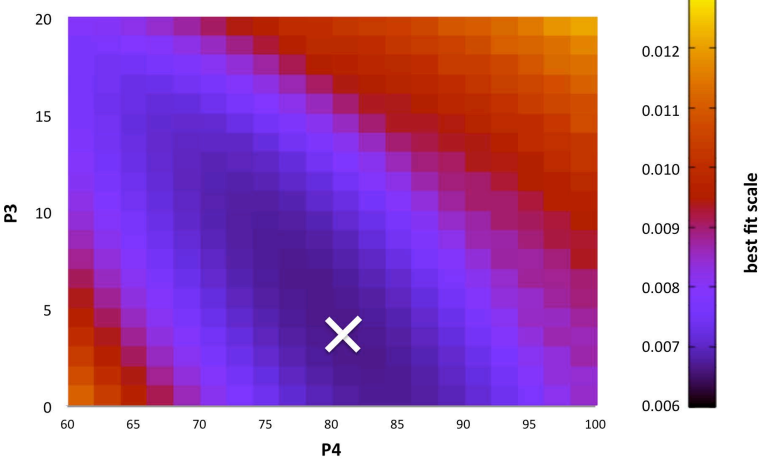

Fig. 7. 